\title{
Proposal for an Alternative Indicator for Testing the Presence of the Political-Budget Cycle in the Case of Tax Policy
}

Milan Křápek, Lucie Formanová

\begin{abstract}
The content of this paper is a proposal for a new explanatory variable that can be used instead of commonly used variables expressing the dates of parliamentary elections. The proposed variable is then used to verify the existence of the impact of the political-budget cycle in the area of taxation on a sample of countries belonging to the European Union (EU28) over the period from 2000 to 2012. Combining the use of this variable and the Pearson correlation coefficient, a statistically significant effect of PBC was identified, particularly in the field of indirect excise taxes, and especially for countries belonging to the group of new EU Member States. The article also contains a comparison of results using traditional indicators which take into account the date of parliamentary elections and the results using a new variable. The results obtained show that with the help of two of the four indicators, statistically significant changes in tax policy in the area of indirect excise duties were identified. When evaluating a new variable, it can be noted that it is a variable which is appropriate for testing the effect of $\mathrm{PBC}$, since not only has the number of statistically significant correlation coefficients been increased, but additionally, illogical results contrary to $\mathrm{PBC}$ theory have not been identified.
\end{abstract}

\section{Keywords:}

political-business cycle, political-budget cycle, tax burden, implicit tax rates, labor, consumption, parliamentary election, European Union

JEL Classification: D72, E62, H20 


\section{Introduction}

This paper deals with the phenomenon of the political-budget cycle and aims to explore the potential relationship between scientific disciplines such as economics and political science. It is, therefore, also necessary to take political factors into account when assessing economic affairs. This is mainly due to the fact that, despite the underlying macroeconomic objectives of said economic policies, their actual realization does not have to correspond to these objectives. Then we can talk about the so-called disruptions in the natural development of the market mechanism, which, according to Slaný (2003), can manifest in the ineffectiveness of practical economic policies. The reason could be the political-business cycle taking place in the political market in which voters express their support for certain political parties. This is, above all, about maximizing votes in an election, and therefore an attractive economic policy is preferred which will bring "positive points" to voters and increase the chances of their (re) election. The implementation of such measures may, however, very often run counter to the underlying macroeconomic objectives, thereby hampering healthy economic developments, causing instability, economic decline, and/or social losses. The main part of the presented paper is the introduction of a new methodical way of expressing the terms of parliamentary elections in testing the presence of the political-budget cycle. This indicator is designed to eliminate deficiencies which so far have existed in the studies of the variables used. The main benefit of this contribution can therefore be considered the design of a new methodical element for testing the occurrence of PBC, its application, and mutual comparison with test results using mainstream variables. The results obtained show that the new variable is satisfactory, as it produces similar results, but often more statistically significant, and thus reveals the weaker presence of the political-budget cycle. The roadmap for the paper is as follows. In the next section, the review of PBC theory is made. The third part includes the review of PBC in the fiscal-policy setting, focusing on tax policy. In the fourth part, the variables for testing the presence of the political-business/budget cycle are introduced. The fifth part includes the objectives of the article. In the sixth part, the data and methodology is stated. The main contribution of the paper is presented in the seventh and eighth part. In the last section, the conclusion is presented.

\section{The historical genesis of examining the political-business or budget cycle}

Dubois (2016) states that the first mention of the political-business cycle can be found in an Åkerman work from 1947. Ten years later, Downs (1957) said: "The parties do not win elections to formulate political programs, but formulate their political programs to win the elections", which became the inspiration for Nordhaus (1975), who then compiled the first model to test the influence of the political- 
business cycle. According to the political-business theory, it should stand that the efforts of newly elected political representatives will be to push unpopular measures in the immediate post-election years, i.e. in the first half of the term, whereas the "pleasurable" policy will be implemented in the second period of the election cycle to increase popularity to the maximum extent (Slaný 2003). This assumption has been empirically confirmed, for example in a study by Akhmedov and Zhuravskaya (2004). Since the days of Nordhaus, however, the empirical investigation of the existence of the influence of the political and economic cycle has undergone considerable development, not only by giving preference to fiscal policy over monetary policy, but by gradual expansion of indicators which can act as an explanatory variable. For this reason, models have been constructed to try to explain the interrelationships between the individual phases of the electoral cycle and changes, especially at the level of fiscal policy, and in a variety of dimensions. Jankủ (2016) then categorizes individual approaches in testing the influence of the electoral cycle in the practical implementation of economic policy in three generations:

The first generation of original models of the political and economic cycle were based on the assumption regarding the irrational decision-making of voters and the opportunistic behavior of political leaders. This generation can include the Nordhaus model, which examines the relationship of economic variables, such as inflation and unemployment rates. This analytical model was introduced at a time of considerable instability in the US economy, which Nordhaus (1975) explained through pre-election manipulations and at a time when the political and economic cycle became a fashionable affair. In addition, there was an American presidential election in 1972, in which the pre-election manipulation of the economy took place (Drazen 2000). Republican candidate Nixon effectively used the social-security system to secure success in the upcoming presidential election. Via a personal letter during the election year, he informed voters that it was he who signed the relevant laws that increased their disposable income. This pre-election strategy was successful and brought about his re-election (Tufte 1978). However, it should be noted that these measures caused high budget deficits that forced contradictory measures during the post-election period. This has prompted an in-depth analysis of the dependencies between the development of macroeconomic variables, the date of the elections, and the votes of voters. Nordhaus (1975) based his model on the assumption of the opportunistic behavior of politicians and the irrational decision-making of their voters. Dubois (2016) mentions that political-business cycle theory was tested by Nordhaus. His model was realized through a trade-off on the example of the Phillips curve. In the first generation of models, we can also include the Hibbs model, which began considering the ideology of political parties while still assuming the irrational voter. Unlike Nordhaus, it works with the assumption that voters have heterogeneous preferences, and therefore politicians seeking re-election have to create a different election campaign to gain electoral favor. Finally, we can draw attention to the fact that both Nordhaus' and Hibbs' models have started to 
be criticized, mainly because of the assumption of voter irrationality. Gradually, the second-generation models began to emerge, influenced by the emergence of the theory of rational expectations, on the basis of which any influence of the politicalbusiness cycle can be rejected, especially because people (voters), due to rational expectations, anticipate perfectly the effects of the enforced economic policy, including pre-election manipulation, and therefore they let themselves be influenced (Dubois 2016). However, Drazen (2000) points out that not all voters have the same information. They continually make errors in judgment, which, according to the theory of rational expectations, should be eliminated. Despite this assertion, the influence of the electoral cycle continued to be investigated. In addition, Jankủ (2016) highlights other signs of this generation, namely signaling behaviors and contrary choices. In addition, models included in this generation work with temporary information asymmetries between political leaders and their voters, which leaves room for manipulation via fiscal policy instruments. Another key actuality is the fact that items affecting the status of the state budget come to the center of attention, and therefore the transition from examining the political-business cycle to the political-budget cycle (hereinafter PBC) moves along. Doležalová (2014) explains that the causes of changes in preferences in research can be sought primarily on two levels. She first mentions the acceptance of the theory of rational expectations, while questioning the interpretation of the real impact of changes in the area of the fiscal and monetary policy on the economy. She also notes that in the $20^{\text {th }}$ century, the independence of central banks was strengthened, which resulted in the loss of influence of political leaders over monetary policy. For this reason, Drazen (2000) and Efthyvoulou (2012) highlight the fact that fiscal policy remains the only potential instrument for implementing electorally attractive economic policies. Even in the second generation of PBC models, models based on the ideology of political parties are emerging, for example the Alesina's rational ideological model from 1987. Then arose the third generation of models, which were based on the moralhazard assumption of Persson and Tabellini (2003) and Shi and Svensson (2006). For example, Shi and Svensson (2006) report that, unlike second-generation models, voters and, this time, politicians themselves do not know the level of political competencies, creating a situation of two-sided information asymmetry. However, voters are still rational and make their decisions in view of the expected level of political leadership, which is, however, unobservable. Nevertheless, the key assumption for these models is the fact that non-governmental policy makers, despite their pre-election manipulation, attempt to make hidden efforts (Hanusch 2010). These tendencies, according to Jankü (2016), can be considered a substitute for the level of their competencies. Regardless of the theoretical assumption, the basic idea of all political-business, budgetary theories remains the same, as well as the idea that there are motives that can create room for legislators to implement an attractive economic policy, irrespective of political affiliation. However, it is important to note that there is one condition that must be fulfilled, and that is the existence of a direct 
democratic system (Sjahrir et al. 2013) in which individual political parties compete (cf. Brender and Drazen 2005, Katsimi and Sarantides 2012 or Dubois 2016).

\section{Examining the political-budget cycle in fiscal policy with a focus on tax issues}

Fiscal policy offers many areas for scientific research. From this point of view, research can be focused on a global macroeconomic level, see Nordhaus (1975), Andrikopoulos (2004) or Štiková (2008), or further on the government's budget balance, see Efthyvoulou (2012), Klomp and Haan (2013) or Doležalová (2014). Other research focuses only on portions of public budgets (expenditure or revenue). Rogoff (1990), Sedmihradská et al. (2011), or Matějová et al. (2015), Plaček et al. (2016), Půček et al. (2016), for example, focus on the composition of the expenditure side. As opposed to the above-mentioned authors, Haselswerdt and Bartels (2015) prefer to examine the revenue side of public budgets, focusing primarily on their most important items, i.e. tax revenues. In the period under review, i.e. 2000 to 2012, the collection of taxes classified according to ESA 2010 methodology (D2 - Taxes on production and imports, D5 - Current taxes on income, wealth, etc. and D9 - Capital taxes) averaged $59.1 \%$ of the total revenues to the state budgets of the countries belonging to the EU28 (Ameco 2017). The above-mentioned authors further argue that citizens are much more sensitive to tax changes instead of the manipulation of public spending, which the authors demonstrated empirically in their study. Ashworth and Heyndels (2002), therefore, refer to the tax area as a very attractive area for implementing a pre-election campaign. Foremny and Riedel (2014) or Yoo (1998) predict that changes resulting in tax increases will be postponed until the post-election years, while their decrease can be anticipated in pre-election or election years. Katsimi and Sarantides (2012) then state that there is a negative relationship between the election cycle and taxation. Smatrakalev (2006) considers tax payers to be voters who can express their opinion in the upcoming elections. Yoo (1998) perceives tax policy not only as one of the main economic policy instruments through which macroeconomic goals can be met, but also instruments that can be manipulated in a political struggle. In spite of the above, examinations of the influence of the political-budget cycle through the variables belonging to tax policy are still rare (cf. Nelson 2000, Ehrhart 2013, Foremny and Riedel 2014). Among authors who have dealt with the relationship between the practical implementation of tax policy and the electoral cycle, the following are concerned: Mikesell (1978), Swank and Swank (1993), Yoo (1998), Nelson (2000), Ashworth and Heyndels (2002) Persson and Tabellini (2003), Petterson-Lidbom (2003), Andrikopoulous et al. (2006), Veiga and Veiga (2007), Katsimi and Sarantides (2012), Ehrhart (2013), Foremny and Riedel (2014).

There is, however, a common consensus in the development of tax policy in relation to $\mathrm{PBC}$ theory that there is no uniform tax instrument as a variable which 
should be included into an analysis. According to David and Formanová (2016), it is possible to divide them into to 2 groups: i) tools for tax-policy determination (nominal and effective tax rates) or ii) indicators expressing the results of its determination (total tax liability or total tax collection). As nominal rates, we can consider the rates which are imposed by the law, which are usually expressed as some percentage. Despite being very easy to obtain, there are some disadvantages because they cannot be considered a sufficiently suitable instrument for testing PBC theory because of their uniformity for all taxpayers on the territory of the state. They do not take into account other aspects influencing final tax liability, such as non-taxable items or tax allowance. Based on that, the effective tax rates are calculated and express what percentage of income each tax payer pays in taxes. The second group of indicators includes total tax collection or total tax liability of taxpayers. The indicator of total tax collection has been frequently used by researchers such as Khemani (2004), Ehrhart (2013) or Morozumi et al. (2007). Nevertheless, according to Foremny and Riedel (2014) or Pettersson-Lidbom (2003) there are some significant disadvantages. Total tax collection can be influenced by factors other than the PBC, such as the development of economy or just by the tax authority's inability to collect taxes. Therefore, instead of this, an alternative indicator for total tax liability can be used. In addition, there are complex indicators expressing the total tax burden of tax payers in individual states, such as traditional tax quota, the world tax index, or implicit tax rates. Within our analysis we are going to use an alternative tax-burden indicators, namely implicit tax rate on labor and consumption.

\section{The factor of holding parliamentary elections as the main explanatory variable in testing the presence of the political-business/budget cycle}

In the context of testing the political-business/budget cycle, it is desirable to focus attention on the determination of an independent variable (excluding the dependent tax policy variable), i.e. a variable expressing the date of any forthcoming parliamentary elections. The determination of the electoral variable can be considered, according to Jankü (2016), as one of the key factors in verifying the presence of political business or, respectively, the budget cycle. However, there is no unified opinion on the issue, so it is possible to use multiple approaches.

The first is a classic dummy variable, which only takes into account the year elections are held. Years in the electoral cycle are classified into pre-election, election, immediate post-election and other. If the authors verify the manipulation in the election year, the dummy variable gets the following values: a value of "1" for election years, and a value of " 0 " for the other years. The classic form of the dummy variable was used, for example, in the studies of the following authors, Yoo (1998), Persson and Tabellini (2003), Pettersson-Lidbom (2003), Akhmedov and Zhuravs- 
kaya (2004), Drazen and Eslava (2010), Efthyvoulou (2012), Foremny and Riedel (2014) or Janků (2016), and can be considered a mainstream indicator.

However, the presence of PBC may be affected by time delays, mainly depending on which part of the calendar year the parliamentary elections take place. The authors who worked on this assumption were: Ashworth and Heyndels (2002), Brender and Drazen (2005), Ehrhart (2013), and Doležalová (2014). The explanatory variable from this category can then be called a dummy variable when taking into account mid-year elections. For example, Doležalová (2014) states that a closer determination of the timing of elections, which appears in econometric models as an independent variable, can significantly improve the results of testing. It is based on the fact that if political leaders know the exact date of the upcoming elections, they will adapt their behavior and choose the ideal timing to start fiscal policy manipulation. In the framework of his work, he verified this hypothesis: " $A$ spring term for parliamentary elections forces the government to manipulate fiscal policy in the year preceding the parliamentary elections." However, from the whole sample examined, the hypothesis was only confirmed in a group of countries belonging to Central Europe, where determining the date of the election has resulted in a higher statistical significance of the regression coefficient of the electoral variable. Brender and Drazen (2005) previously dealt with the same issues. The authors draw attention to the fact that the use of the dummy variable " 1 " in the election year is the most frequently used method of expressing the election date, however, regardless of the time at which the elections take place. The authors state that if the elections are held in the second part of the year, the dummy variable expressed as such may capture the pre-election manipulation of fiscal policy instruments. However, if they are already in the first half of the year, then the chosen variable will capture post-election effects. For these reasons, the authors submit an alternative solution. If the elections are held in the first half of the year, the dummy variable will already be "1" during the pre-election year. Ehrhart (2013) then used the authors to modify the dummy variable. He also included, besides the classic classification of the years of pre-election, election and non-election, the dummy variable (after this modification) into his research. Just like Doležalová (2014), he took into account the fact whether the elections took place in the first or the second half of the calendar year. However, the inclusion of an alternative dummy variable in comparison with the original version did not bring different conclusions regarding the influence of the political-budget cycle in the area of taxation. The question of determining the dummy variable, depending on the exact date of the parliamentary elections, was also addressed by Ashworth and Heyndels (2002), who identified the moment when an attractive tax policy could be launched.

However, it is possible to find out among the authors that, in particular, the classically chosen dummy variable may fundamentally distort the results of the whole test. For this reason, alternative methods of determining the electoral variable begin to emerge; for example, Franceze (2002) modifies the classical dummy 
variable, which in this case considers the particular month of the elections. The variable in the election year is $M / 12$, in the pre-election period (12-M)/12, where $M$ is the month of the election. The variable in the rest of the years has the value 0 . Alternatively, the specific day of the elections can be implemented in the calculation. In addition, Schuknecht (2000) determines the dummy transformation depending on the time at which the fiscal expansion or restriction is expected. In these years, the dummy variable gets 1 , and 0 in the others. Andrikopoulos et al. (2006) then take into account how long the political leaders have been in power. Another possible solution comes from Bracco et al. (2013), who claim that attention should be paid to the development of the electoral cycle itself. They propose the use of a variable that takes into account the length of time since the last election took place (for example, the value of 0 means that elections are held in the year in question, the value of 1 for the year immediately following, etc.), but it must always be stated that the maximum value will be equal to the length of the election cycle.

Based on the above, it is obvious that the electoral variable, as an explanatory variable, is often a subject of discussion, and there is no consensus as to what form the term of election should be when testing for the presence of PBC. Its determination can then be considered the fundamental decision of every research survey which verifies the presence of the political-budget cycle, because the choice itself can influence the conclusions of the study.

\section{The objectives of the paper}

Based on the above-mentioned theoretical overview on PBC testing in the area of taxation, the main objective of the contribution is to define a new explanatory variable representing the date of the parliamentary elections. Furthermore, the partial objective is to verify the existence of PBC's influence in the taxation area on the example of an alternative indicator of the tax burden, i.e. indicators of the implicit tax rate (labor and consumption) in the time frame from 2000 to 2012 in the territory of 28 European Union countries. Testing will be done not only for the entire sample survey, but also for subcategories of countries, i.e. the original and new EU Member States to identify potential differences in results. Furthermore, the partial objective is to test the existence of PBC effects even by means of the other methods of determination of the independent variables mentioned above.

\section{Data and methodology}

In the position of the explanatory variable, an alternative indicator of the tax burden will be used, namely the indicator of the implicit tax rate from work (hereinafter ITRL) or from consumption (ITRC). Due to the unavailability of data for the whole sample of countries surveyed, implicit capital rates were not used. In the case of 
ITRL, this is the tax burden on taxpayers from personal income tax. According to Eurostat methodology (2017), this indicator expresses the share of taxes on the total compensation of employees and therefore gives an overview of the tax burden on taxpayers of personal income tax, namely, the focus is on dependent activities. This indicator was chosen primarily because there is a presumption that taxpayers of this tax are also registered voters, and therefore lawmakers pay increased attention to this kind of tax when creating their electoral campaigns (Johnson et al. 2005). In addition, Katsimi and Sarantides (2012) point to their direct impact on taxpayers' disposable income. Therefore, we can consider direct taxes as a visible part of taxes for taxpayers. The tax burden on households by consumption taxes is expressed by the ITRC, which is defined as the proportion of total consumption duties and total consumption expenditure of households in the economic territory. The reasons for including general and specific excise taxes can be found, for example, in Ehrhart (2013). As part of PBC testing, there is room for analysis of the development of individual default rates individually. Moreover, they are also an appropriate indicator for potential testing of whether changes in the tax structure occur within preelection manipulation.

The indicators ITRL and ITRC are presented in percentage form and indicate the tax burden on specific activities in individual countries over the period 2000-2012. From input data, the pace of growth was calculated. The values state the percentage change of the tax-burden indicator in comparison with previous years (Eurostat 2016).

The terms of parliamentary elections were obtained and verified from the International Foundation for Electoral Systems (2017), European Election Database (2017) and Election Resources (2017). In the observed time period, there were 90 parliamentary elections.

In the position of the explanatory variable, the conditional factor in the form of the dates of the parliamentary elections will be used in four forms. First, PBC will be tested using the classic dummy variable, i.e. the variable is " 1 " in the election year and " 0 " in non-election years. Additionally, the value " 1 " is assigned to the preelection year and " 0 " to other years. Consequently, the testing will be carried out by modifying the classic dummy variable, which will take into account the half-year of the parliamentary elections. In determining this, we draw on studies by Brender and Drazen (2005), Ehrhart (2013) and Doležalová (2014).

The last possible way of determining the explanatory variable involves the use of a new alternative variable considering the holding of parliamentary elections: the "annual pressure", the definition of which is defined in the following part of this work. The "annual pressure" indicator is based on the political business, resp. political budget theory, which suggests that more pressure is being put on politicians to make popular moves (i.e. to implement an attractive tax policy) around the term of parliamentary elections as opposed to in the middle of the electoral cycle 
when they perform rather rational and unpopular steps among voters (Slaný 2003). This feature takes into account developments even after the elections, since laws which were passed before the elections often have a delayed effect on items that affect taxpayers' final tax liability. The new variable is based on the cosine function with a period corresponding to the time of the next ordinary parliamentary elections. The maximum, the value of " 1 ", takes up at the time of the elections, while the minimum " 1 " takes halfway through the electoral cycle. The curve is the simplest case where early elections do not occur, it is continuous.

For example, for a four-year cycle we get a function (Formula 1); for a five-year cycle the function is defined similarly (Formula 2). Graphs of these functions are shown in Figure 1.

$$
\begin{aligned}
& f(x)=\cos \left(\frac{x \pi}{2}\right) \\
& f(x)=\cos \left(\frac{2 x \pi}{5}\right)
\end{aligned}
$$

Figure 1

Election cycle curve (4-year and 5-year cycle)

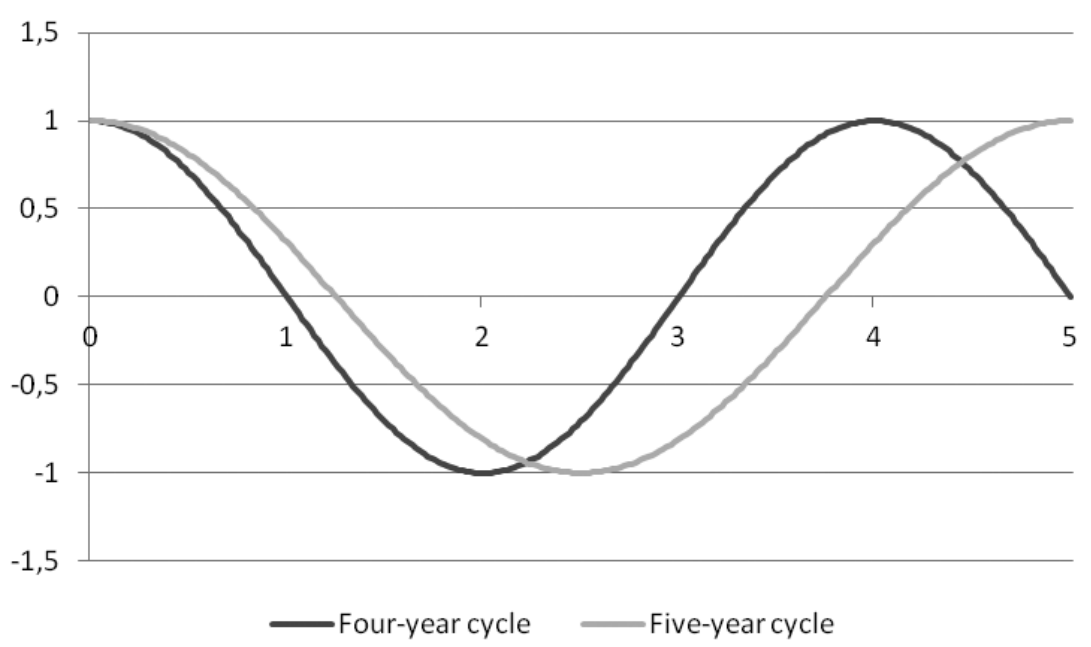

Source: Authors

Generally, for any cycle length, this curve is a function (3) where d indicates the length of the election cycle, which does not necessarily have to be the whole number. 


$$
f(x)=\cos \left(\frac{2 x \pi}{d}\right)
$$

We determine the date of the election according to whether it was in the first or second half of the year. Thus, with the election time in the first half of the year, we determine a transition between the end of March and the beginning of April, which is one quarter. Assuming an even distribution, the results will not be distorted (deflected) on either side. Similarly, for elections held in the second half of the year, we chose an election time between late September and early October.

\section{Figure 2}

The course of the curve according to the half of the year in which the elections took place

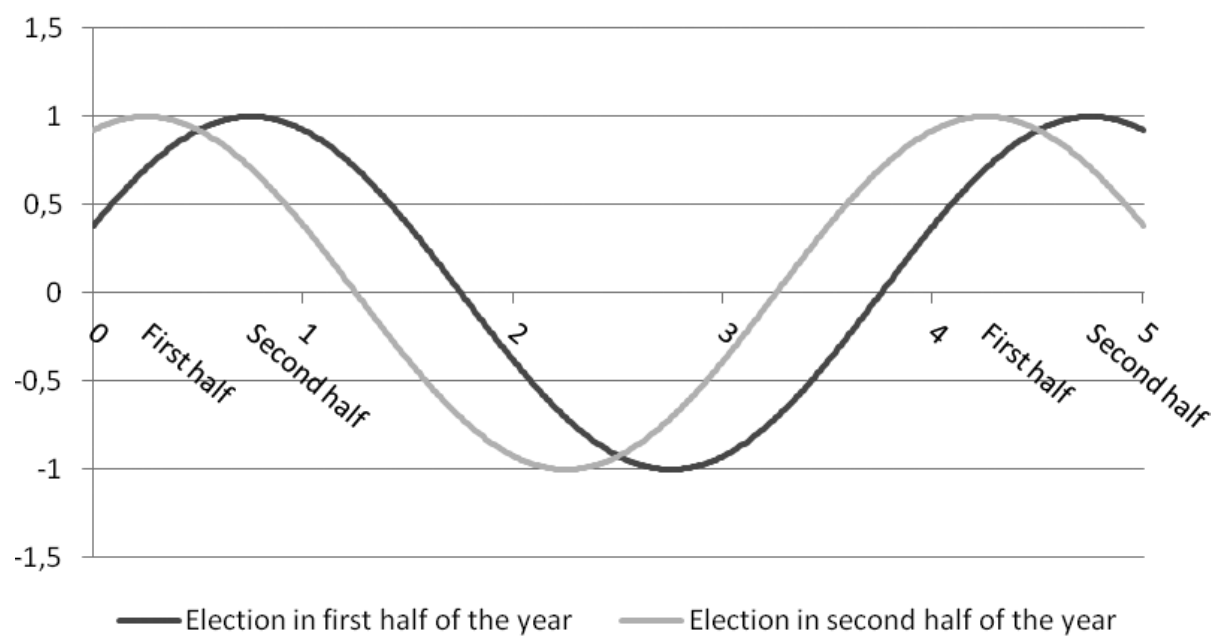

Source: Authors

However, there are various exceptions in the countries of the European Union (EU 28), or changes in the electoral cycle. In the event of a planned change in mandate, we assume that the period of function determining the pressure on policies will change immediately after the election. The function of pressure is expressed as the function of going to the next cycle, which has a different length, however. Due to the fact that the transition to another period is assumed already at the time of the election, i.e. when the function becomes " 1 ", the new cycle starts by just this value, and the transition is continuous.

In the case of early elections, the function will become discontinuous, see Figure 3 , because at the time of the early elections the curve will immediately rise to its maximum. 
Figure 3

Election cycle curve development in the case of early elections

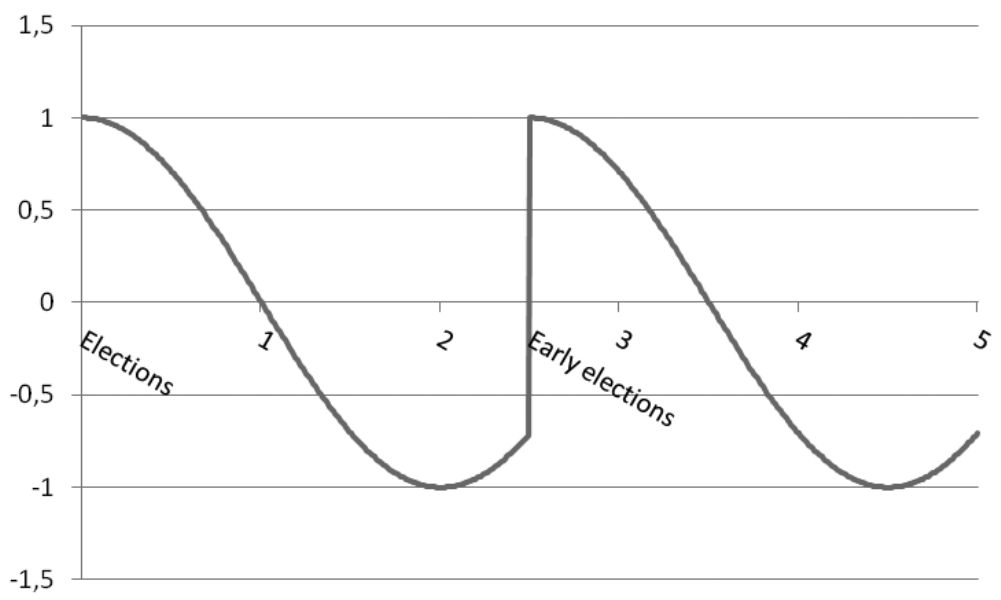

Source: Authors

We assume that pressures on policies build up throughout the year. The resulting variable can be called annual pressure, and it is a cumulation of pressure over one year. This is individually determined in each year and for each country by the content of the subgraph under the curve bound by the beginning and the end of the reference year. Thus, we get positive values at a time when the PBC theory is expected to be rather popular (i.e. the implementation of electorally attractive fiscal or tax policy) and negative values at a time when restrictive (i.e. unpopular) steps can be foreseen. As can be seen in Figure 4 below, in an election year (from the beginning of the year marked 0 ) until the end of this year, the pressure is high and is equal to the content of the part marked I. In year 2, the pressure is quite the contrary, it is equal to the content of part II with a negative sign. In the third year, part of the year is negative pressure and in the second part positive. Positive pressure is higher here, so the resulting annual pressure will be a positive number that is obtained by subtracting the content of part III from part IV. In case of early election, we assume that the politicians do not have any time to make popular steps. Therefore, we can say that the early elections are not detected before elections. The attractive tax policy settings can be identified after election. Based on that, the function "annual pressure" is discontinuous. At the time of the early elections the curve will immediately rise to its maximum. 


\section{Figure 4}

Illustration of the calculation of annual pressure

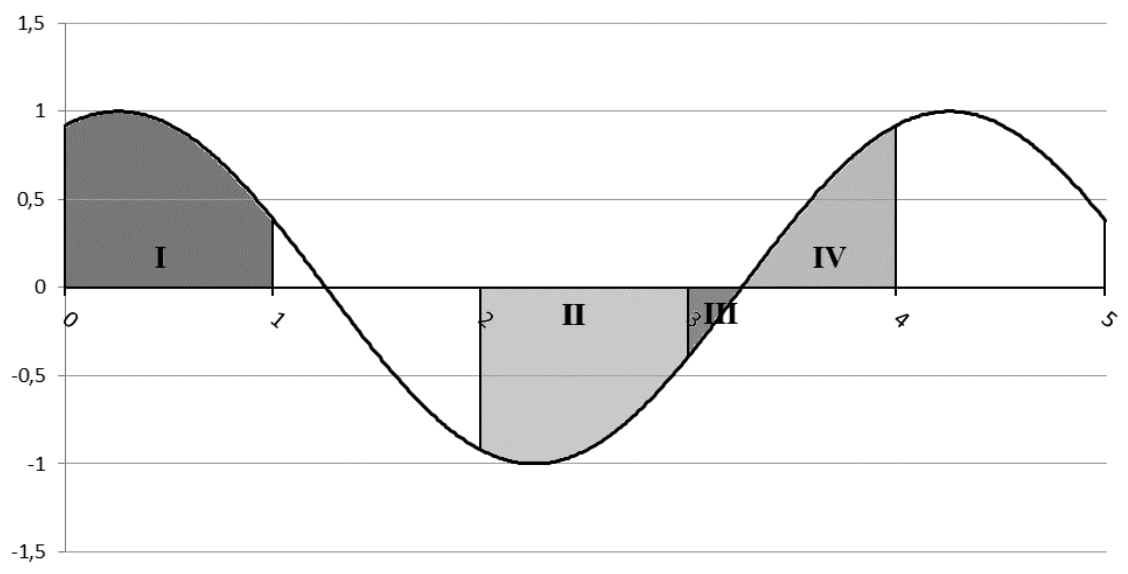

Source: Authors

The theoretical maximum annual pressure is " 1 ", the smallest is " -1 ", but these values are never achieved. These are the values that would apply to an endless length of the election cycle. Due to the maximum length of the electoral cycle 5 and the method of determining the date of elections, we will reach a maximum value of " 0.91 " and a minimum of " -0.95 ".

In the context of testing the existence of PBC's influence, the following assumption will be verified: "The upcoming parliamentary election represented by the increasing value of the [annual pressure] indicator has a negative impact on the level of the tax burden indicator, i.e. the decreasing year-on-year growth rate of the ITRL or ITRC." The Pearson correlation coefficient will be used to verify the dependence between the above variables. The statistical significance of the correlation coefficient will be determined by the t-test. The correlation coefficient is significant if its absolute value exceeds the critical value.

Furthermore, we are going to analyze the development of each implicit tax rate (labor and consumption) separately, and like the work of Doležalová (2014), we are going to divide the EU countries into 2 groups (old and new member states) to test the influence of PBC individually for both. Those considered to be new European member states countries have become members of the EU since 2004 (Bulgaria, Croatia, Cyprus, Czech Republic, Estonia, Hungary, Latvia, Lithuania, Malta, Poland, Romania, Slovakia, Slovenia). Old EU member states include Austria, Belgium, Denmark, Finland, France, Germany, Greece, Ireland, Italy, Luxembourg, the Netherlands, Portugal, Spain, Sweden and UK. Our analysis includes 28 countries (15 old and 13 new ones) from 2000 to 2012. Our source data contains 364 observations for each representative of implicit tax rates. 


\section{Results}

The following table, Table 1, lists the results of testing for the presence of PBC, using all of the defined methods for determining an independent variable in the literature search. Columns 3 and 4 present the results for the classic form of the dummy variable in the pre-election and election periods, whereas column 5 contains the test results using the dummy variable considering the half-year of the elections, and in column 6 the values of the correlation coefficients obtained results in case of use new alternative indicator annual pressure. It should be noted that all of these values are determined at a standard $5 \%$ significance level.

From the results of the correlation analysis of the pre-election period (column 3 ), it is clear that most (5 out of 6) obtained results are not statistically significant, so no conclusions can be drawn regarding the presence of PBC. Only in the case of the original EU countries was the presence of PBC confirmed; in the case of ITRL. In the case of the dummy variable for the election year (column 4), statistically significant results were obtained for the new member states of the European Union in the example of the tax burden on consumption. Based on this, it can be stated that during the electoral years an attractive tax policy in the area of excise duties was implemented in the given territory. From the point of view of dependence intensity, the dependence is very weak, but still statistically significant. The values of the other correlation coefficients are again not statistically significant, but as in the case of ITRL in the new states, the ITRCs of all EU countries surveyed indicate a possible sign of decline and hence the existence of PBC. However, a completely different result contradicting the PBC theory was obtained on a sample of original states; a statistically significant increase in the tax burden of the ITRL indicator. If we summarize the achieved results using a traditional indicator (i.e. a classical dummy variable), taking into account only the year of the parliamentary elections, both in the case of pre-election and electoral variants, we would conclude that the variable as defined produces only two statistically significant results, which also correspond to the PBC theory.

The resulting values of the correlation coefficients using the dummy variable which take into account the midterm of parliamentary elections (column 5) do not carry any statistically significant value. It is quite clear that this dummy variable, which could, for example according to Brender and Drazen (2005), Ehrhart (2013) or Doležalová (2014), lead to a more accurate assessment of the results, does not even achieve any statistical significance of the correlation coefficient in any of these cases.

As has been stated in the methodological section of this paper, the new "annual pressure" indicator is designed to more accurately reflect the moment when political leaders are being pressured to change tax policy to influence voter decision-making in upcoming parliamentary elections. In addition, it eliminates the 


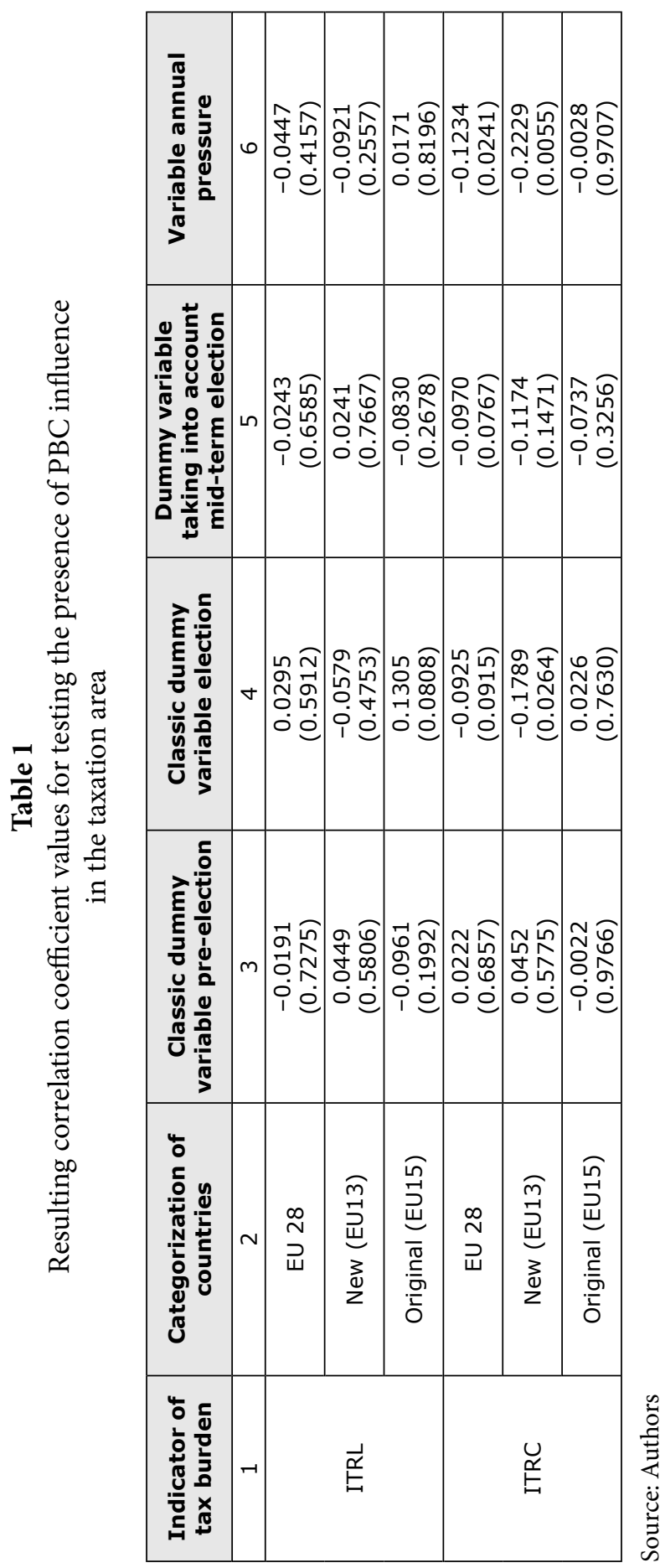


deficiencies of both forms of dummy variables, since it reflects instances such as the unpredictability of early elections or changes in the electoral cycle. According to the calculated correlation coefficients (column 6), it can be argued that, with increasing pressure on policies, there is a particular manipulation concerning excise duties. This has been demonstrated for all EU Member States (very weak dependence), with the categorization of countries mainly for the new member states. For the original states, the value of the correlation coefficient does not have a statistically significant value but indicates a possible decline, which could point to the implementation of an attractive tax policy in the field of indirect taxes. In the case of the implicit tax rate for work, statistically insignificant results were obtained, but the correlationcoefficient values in the case of the new states point to potential drops in the tax burden, whereas in the original states, they have completely different conclusions than expected, based on the PBC theory. If we recapitulate the results of the PBC occurrence in the tax area, we find that, as in the case of the classically expressed dummy variable, there have been statistically significant decreases in the ITRC in the new EU countries, which confirms the incidence of PBC in indirect taxation.

\section{Discussion}

If we only focus on evaluating the implementation of tax policy dependent on the electoral cycle in the territory of the European Union, we find that tax policy was abused by political representatives in the period under review, especially in the area of indirect excise duties; especially on the sample of the new member states of the European Union. This conclusion was confirmed in the election year in the case of testing using the classical dummy variable followed by the "annual pressure" indicator. The results achieved correspond to the conclusions of Formanová and Mádr (2015), who tested the impact of PBC through tax structure manipulation in the 11 new EU member states. It is worth mentioning that in both studies, the classical expression of the dummy variable was used. Furthermore, we can draw attention to the fact that in our case, statistical significance was confirmed not only by this method of determining the explanatory variable, but also by the new alternative variable "annual pressure". Consequently, we can confirm the presence of the political-budget cycle in the implementation of the practical tax policy in the field of indirect taxes, especially in the new member states of the European Union. However, the main objective of this paper was to evaluate the new variable represented by the date of parliamentary elections. From the above, it is quite clear that the dummy variable, which takes into account mid-year elections and should have increased the precision of the results, did not manage to be statistically significant in the correlation coefficient in either case. For this reason, this variable may be discarded in future $\mathrm{PBC}$ verification. The results obtained correspond to the conclusions of Ehrhart (2013), who also used the indicator while not obtaining statistically significant results. There is also Doležalová (2014), who evaluated the indicator as 
being statistically significant only on a small sample of the surveyed countries overall, but still marked it as statistically insignificant. The resulting conclusions on the presence of $\mathrm{PBC}$ in implicit tax rates (labor and consumption) for the remaining two variables are very similar. From the point of view of the number of statistically significant correlation coefficients, the "better" indicator can be seen as the "annual pressure" alternative, for which we do not have statistically significant results which contradict $\mathrm{PBC}$ theory. For this reason, we can mark the newly proposed variable suitable for verifying the presence of $\mathrm{PBC}$.

\section{Conclusion}

The presence of the political-budget cycle in the area of taxation has been verified in a sample of $28 \mathrm{EU}$ Member States over the period 2000 to 2012. In the position of the explanatory variable, implicit tax rates on labor and consumption were chosen which represented both direct and indirect taxes within the tax systems of European countries. In the position of the explanatory variables, there was a classical dummy variable testing tax policy manipulation at two points in time (i.e. in the pre-election and the election year), a modified dummy variable reflecting mid-year parliamentary elections, and the newly proposed variable of "annual pressure". In the end, the results were compared in order to evaluate the newly designed variable. The results achieved are as follows: 2 of the 4 used indicators were confirmed at a $5 \%$ level of significance, the tendencies of the representatives of the legislature to manipulate the tax policy, depending on the date when elections are held while taking into account the date of the parliamentary elections. It has been found that indirect taxes on excise duties are particularly prone to manipulation with tax policy.

Based on the results obtained, the suitability of the newly proposed variable can also be assessed. In its use, the number of statistically significant values of the correlation coefficient increased, followed by an increase in intensity, and the new variable did not produce illogical results that contradicted $\mathrm{PBC}$ theory. In the final evaluation of the alternative variable which takes into account the date of the parliamentary elections, the results point to the suitability of the authors' proposed variable for modelling pressure, as it achieves similar results, but statistically more significant, and thus also reveals the weaker presence of the political-budget cycle. The relatively short time frame (just 2000 to 2012) can be considered a limitation of the conducted research, which was due to the inaccessibility of input data in the case of implicit tax rates. Certain restrictions also imply the use of the basic statistical apparatus (Pearson's correlation coefficient) and the definition of an alternative indicator through the mid-year in which the elections took place or the number of election cycles that have taken place since the first free elections. For these reasons, it is a matter for further research to choose a tax-rate indicator that has a longer time series (e.g. tax collection) or to extend the $\mathrm{PBC}$ test by means of econometric 
models (e.g. panel-data analysis), or to modify and improve the value of the defined indicator here of "annual pressure".

\section{References}

Akhmedov, Akhmed and Ekaterina Zhuravskaya. 2004. "Opportunistic Political Cycles: Test in a Young Democracy Setting." Quarterly Journal of Economics 19(4), 1301-1338.

Alesina, Alberto. 1987. "Macroeconomic Policy in a Two-Party System as a Repeated Game." Quarterly Journal of Economics 102(3), 651-678.

Ameco. 2017. Macro-Economic Database AMECO. Available at https://ec.europa. eu/info/business-economy-euro/indicators-statistics/economic-databases/ macro-economic-database-ameco_en (last accessed 31 March 2017).

Andrikopoulous, Andreas. 2004. "Fiscal Policy and Political Business Cycle in the EU." Journal of Political Economics 20(1), 125-162.

Andrikopoulos, Andreas, Ioannis Loizides and Kyprianos Prodromidis. 2006. “Taxation and Political Business Cycles in EU Economies." Applied Economics 38(15), 1761-1774.

Ashworth, John and Bruno Heyndels. 2002. "Tax Structure Turbulence in OECD Countries." Public Choice 111(3/4), 347-376.

Bracco, Emanuele, Francesco Porcelli and Michela Redoano. 2013. "Political Competition, Tax Salience and Accountability: Theory and Some Evidence from Italy." Working Paper.

Brender, Adi and Allan Drazen. 2005. "Political Budget Cycles in New versus Established Democracies." Journal of Monetary Economics 52(5), 1271-1295.

David, Petr and Lucie Formanová. 2016. "Electoral Cycle and Tax Policy: Determination of Income Tax Variables: Case of the Czech Republic." ProceediaSocial and Behavioral Sciences 220, 95-104.

Doležalová, Jitka. 2014. Politický cyklus a fiskální politika: Význam jejich vztahu pro hospodářskou politiku. Brno: Masarykova univerzita.

Downs, Anthony. 1957. "An Economic Theory of Democracy." Journal of Political Economy 65, 135-150.

Drazen, Allan. 2000. “The Political Business Cycle after 25 Years.” NBER Macroeconomic Annual 15, 75-117.

Drazen, Allan and Marcela Eslava. 2010. "Electoral Manipulation via Voter-Friendly Spending: Theory and Evidence." Journal of Development Economics 92(1), $39-52$. 
Dubois, Eric. 2016. “Political Business Cycles 40 Years after Nordhaus." Public Choice 166(1), 235-259.

Efthyvoulou, Georgios. 2012. "Political Business Cycles in the European Union and the Impact of Political Pressures.” Public Choice 153(3-4), 295-327.

Ehrhart, Hélène. 2013. "Elections and the Structure of Taxation in Developing Countries." Public Choice 156(1), 195-211.

Election Resources. 2017. Election Resources on the Internet. Available at http:// www.electionresources.org/ (last accessed 12 March 2017).

European Election Database. 2017. Parliamentary Elections. Available at http:// www.nsd.uib.no/european_election_database/election_types/parliamentary_elections.html (last accessed 12 March 2017).

Eurostat. 2016. Implicit Tax Rates. Available at https:/ec.europa.eu/taxation_customs/sites/taxation/files/resources/documents/taxation/gen_info/economic_analysis/data_on_taxation/implicit-tax-rates.xlsx (last accessed 30 December 2016).

Eurostat. 2017. Methodological and Explanatory Notes. Available at http://ec.europa. eu/taxation_customs/sites/taxation/files/resources/documents/taxation/ gen_info/economic_analysis/tax_structures/2014/methodology.pdf (last accessed 12 January 2017).

Foremny, Dirk and Nadine Riedel. 2014. "Business Taxes and the Electoral Cycle." Journal of Public Economics 115, 48-61.

Formanová, Lucie and Michal Mádr. 2015. "Elections and the Tax Structure in the Post-Socialist EU Member States." Scientific Papers of the University of Pardubice 23(37), 5-13.

Franceze, Robert. 2002. "Electoral and Partisan Cycles in Economic Policies and Outcomes." Annual Review of Political Science 5, 369-421.

Hanusch, Marek. 2010. “The Economy and Political Budget Cycles.” APSA 2009 Toronto Meeting Paper.

Haselswerdt, Jake and Brandon L. Bartels. 2015. "Public Opinion, Policy Tools, and the Status Quo: Evidence from a Survey Experiment." Political Research Quarterly 68(3), 607-621.

International Foundation for Electoral Systems. 2017. Election Guide. Available at http://www.electionguide.org/elections/past/ (last accessed 12 March 2017).

Janků, Jan. 2016. “Podmíněný politicko-rozpočtový cyklus v zemích OECD.” Politická Ekonomie 2016(1), 65-82.

Johnson, Paul, Frances Lynch and John Geoffrey Walker. 2005. "Income Tax and Elections in Britain, 1950-2001.” Electoral Studies 24(3), 393-408. 
Katsimi, Margarita and Vassilis Sarantides. 2012. "Do Elections Affect the Composition of Fiscal Policy in Developer, Established Democracies?" Public Choice 151(1-2), 325-362.

Khemani, Stuti. 2004. "Political Cycles in a Developing Economy: Effect of Elections in the Indian States." Journal of Development Economics 73(1), 125-154.

Klomp, Jeroen and Jakob de Haan. 2013. "Political Budget Cycle and Election Outcomes." Public Choice 157(1-2), 245-267.

Matějová, Lenka, Michal Plaček and Ochrana František. 2015. "Political Business Cycle in Local Government: Case Study of Czech Municipalities." Proceedings of the $19^{\text {th }}$ International Conference: Current Trends in Public Sector Research. Brno: Masarykova univerzita, s. 142-148.

Mikesell, John L. 1978. "Election Periods and State Tax Policy Cycle." Public Choice 33(3), 99-106.

Morozumi, Atsuyoshi, Francisco José Veiga and Linda Gonçalves Veiga. 2014. "Electoral Effects on the Composition of Public Spending and Revenue: Evidence from a Large Panel of Countries." Working Paper.

Nelson, A. Michael. 2000. "Electoral Cycles and the Politics of State Tax Policy." Public Finance Review 28(6), 540-560.

Nordhaus, William D. 1975. “The Political Business Cycle." The Review of Economic Studies 42(2), 169-190.

Persson, Torsten and Guido Tabellini. 2003. "Do Electoral Cycles Differ across Political Systems?” No 232, Working Papers, IGIER (Innocenzo Gasparini Institute for Economic Research), Bocconi University.

Pettersson-Lidbom, Per. 2003. "A Test of the Rational Electoral-Cycle Hyphothesis." Research Pápera in Economics.

Plaček, Michal, Milan Půček, František Ochrana, Milan Křápek and Matějová Lenka. 2016. "Political Business Cycle in the Czech Republic: Case of Municipalities." Prague Economics Papers 25(3), 304-320.

Půček, Milan, Michal Plaček and Ochrana František. 2016. "Do the Data on Municipal Expenditures in the Czech Republic Imply Incorretness in their Management?" Ekonomie a management 19(4), 89-103.

Rogoff, Kenneth. 1990. "Equilibrium Political Budget Cycle." American Economic Review 80(1), 21-36.

Schuknecht, Ludger. 2000. "Fiscal Policy Cycles and Public Expenditure in Developing Countries." Public Choice 102(1/2), 115-130.

Sedmihradská, Lucie, Rudolf Kubík and Jakub Haas. 2011. "Political Business Cycle in Czech Municipalities.” Prague Economic Papers 2011(1), 59-70. 
Shi, Min and Jakob Svensson. 2006. "Political Budget Cycles: Do they Differ across Countries and why?" Journal of Public Economics 90(8-9), 1367-1389.

Sjahrir, Bambang Suharnoko, Krisztina Kis-Katos and Günther G. Schulze. 2013. "Political Budget Cycle in Indonesia at the District Level." Economics Letters $120(2), 342-345$.

Slaný, Antonín. 2003. Makroekonomická analýza a hospodářská politika. Praha: C. H. Beck.

Smatrakalev, Georgi S. 2006. “Taxes and Elections." Wageningen Academic Publishers, 525-545.

Swank, Otto H. and Job Swank. 1993. "In Search of the Motives behind US Fiscal Macroeconomic Policy." Applied Economics 25, 1013-1022.

Štiková, Radka. 2008. "Modely politického cyklu a jejich testování v podmínkách ČR.” Working Paper IES 2017/18.

Tufte, R. Edward. 1978. Political Control of the Economy. New Jersey: Princeton University Press.

Veiga, Linda and Francisco Veiga. 2007. "Political Business Cycles at the Municipal Level.” Public Choice 131(1-2), 45-64.

Yoo, Keum-Rok. 1998. "Intervention Analysis of Electoral Cycles: The Case of Japan.” Public Choice 96(3-4), 241-258. 